\title{
ВПЛИВ ЕМОЦІЙНИХ СТАНІВ НА РОЗВИТОК ОСОБИСТОСТІ
}

Удк: 159.923

\section{Маслюк Андрій Миколайович}

Кандидат психологічних наук, старший науковий співробітник лабораторії загальної психологї та історії психологї ім. В. А. Ромения Інституту психологї імені Г. С. Костюка НАПН Украӥни, Київ (Украӥна)

\begin{abstract}
Анотація. В статті розглядається проблема емоційних станів особистості. Здійснено теоретичний аналіз характерних проявів емоиій та їхній вплив на розвиток особистості. Зокрема, уточнено особливості емочійності украӥнського народу, крізь призму родинного виховання. Констатується важливість сповідування украӥнською інтелігенцією «філософії серия», де серие основа фізичного і духовного життя людини, ї̈ емочійності, моральності. 3'ясовано, щуо український емоціоналізм у сучасних умовах війни на сході Украӥни має бути врахований під час реабілітації учасників військових дій. Для відновлення фізичного й психічного здоров'я важлива підтримка родини.
\end{abstract}

Ключові слова: : виховання, емоиія, моральність, особистість, переживання, родина, розвиток.

Постановка проблеми. Розуміння сучасного розвитку людини в урбанізованому суспільстві ставить перед психологічною наукою нагальне завдання переглянути усталені аксіологічні характеристики особистості, оскільки дотеперішні наукові набутки містять у собі чимало суперечностей. Наукові досягнення поціновуються ступенем практичного застосування. Л. Виготський вказував на те, що й психології потрібно чекати піднесення від зіткнення з життям. Вираження внутрішнього через зовнішнє $є$ сутнісною ознакою життя людини через стани, дії, переживання. Емо- ційні переживання забезпечують цей процес становлення, тобто власного перетворення особистості через значущі об'єкти, явища, інших суб'єктів. Починаючи з дитинства події проектуються й залишаються наближеними до основних життєвих інтересів. Особистість виступає суб'єктом і намагається реалізувати свої можливості, бути автором свого життя. Вплив емоційної сфери на становлення й розвиток особистості є, на наш погляд, стосовно українців, визначальним.

I тим не менш, зміст психологічних поглядів представників української діаспори XX 
століття на емоційність українців, залишається без належного науково-психологічного осмислення, не кажучи вже про потребу в узагальненні відомих на цей час вказаних поглядів.

Аналіз останніх досліджень і публікацій. Проблема дослідження емоційних станів перебувала в центрі уваги таких вчених: П. Анохін, Ф. Василюк, Л. Виготський, У. Джеймс, К. Ізард, Л. Куліков, М. Левітов, Ф. Лерш, С. Максименко, П. Сімонов, В. Юрченко та ін. Незважаючи на наявність значної кількості праць, далека від належного осмислення стосовно емоційності українців багата спадщина представників української діаспори в США, Канаді, Австралії та Європі.

Формулювання цілей статті. Метою статті є дослідження впливу емоційних станів на розвиток особистості та українського народу зокрема.

Виклад основного матеріалу дослідження. «Особистість - це результат складної взаємодії шести систем: гомеостатичної, спонукальної (система драйвів), емоційної, перцептивної, когнітивної та моторної» [3, с. 55]. Ми розуміємо, що кожна з систем є автономною, але водночас і взаємозалежною. Проаналізуємо емоційну систему та іiї вплив на становлення особистості.

На думку сучасного класика психології С. Д. Максименка, особистість починається 3 любові. Цю тезу можна розгортати в різних напрямках, парадигмах, але ми вважаємо, що любов об'єднує й конструює особистість. Любов всеохоплююча й може піднести особистість до небачених обріїв або знищити ii. Такою є сила емоцій. Ми не будемо вдаватися до детального аналізу класифікації емоцій, а лише зазначимо, що на теренах України в стінах Києво-Могилянської академії вже на початку XVIII століття Феофаном Прокоповичем була створена вперше у вітчизняній психології деталізована класифікація емоційних станів людини (зокрема таких, як любов, турбота, тривога, надія, впевненість, ревність, радість, сором, щастя, легкодушність, ненависть, гнів, обурення, жах, розпач, заздрість, безсилля, байдужість, корисливість, безтурботність, смуток, втіха, страх). До речі, автор вважав, що першоджерелом всіх почуттів людини $є$ любов, яка має дві властивості - бажати добра і не бажати зла: «... коли користуємося першою властивістю любові, то ми любимо, прагнемо, надіємося, радіємо з того, що здається, веде нас до певних речей, коли ж другою - то ми відвертаємося, гніваємося, обурюємось, боїмось, співчуваємо, соромимось, втрачаємо надію, відчуваємо біль, чого, очевидно, уникаємо, як це ясно дослідникові» [8, с. 87].

Також Ф. Прокопович вказує на той факт, що любов впливає на організм людини та виявляється у мові. Якщо особистість любить, то іiї мова буде неспокійною, жвавою, а також міститиме вигуки, замовчування, сумніви, повторення, виправлення та ін. Щодо інших емоцій, то зокрема, вчений розглядав не- 
нависть як схильність душі до зла, прагнення до чогось злого, а гнів як хворобливе бажання помсти за реальну або уявну неповагу до власного «Я» або рідних, що також виявляється у поведінці. Таким чином, починаючи з XVIII століття ми маємо розроблену детальну вітчизняну класифікацію емоційних станів людини, що засвідчує наявність взаємозв'язку між поведінкою людини та емоційними станами.

П. Сімонов, ототожнюючи категорії «переживання» та «емоція», розробив інформаційну теорію емоцій, вважаючи, що: «... інтелектуальне осягнення світу, що закінчилося виникненням людської свідомості (тобто знання, яке може бути передане, розділене 3 іншими членами спільноти), виявилося доповнене механізмом співпереживання, співчуття, властивістю осягнення внутрішнього світу іншого шляхом його «перенесення» на свій власний емоційний досвід» [9, с. 31]. За теорією дослідника, емоції визначаються певною актуальною потребою й можливістю ії задоволення, що характеризується ймовірністю досягнення мети. Позитивні емоції виникають у ситуації надлишку прагматичної інформації порівняно з раніше існуючим прогнозом або в ситуації збільшення вірогідності досягнення мети (якщо генезу емоцій розглядати в іiї динаміці). Негативні емоції є реакцією на падіння вірогідності досягнення мети в процесі діяльності суб'єкта. В концепції П. Сімонова багатогранність емоцій визначається багатогранністю потреб.
Емоцій стільки, скільки потреб. У людини вітальні потреби (голод, спрага) доповнені соціальними й ідеальними потребами. Об'єднання вітальних з соціальними потребами створюють етнічні потреби, які також можуть бути джерелом емоцій. Прагнення максимізувати - підсилити, повторити позитивні емоції й мінімізувати - перервати, запобігти негативним, визначає регуляторні функції емоцій, їхню цілеспрямовуючу роль в організації поведінки.

Р. Плутчік визначає емоцію як комплексну соматичну реакцію, що обумовлена конкретним адаптивним біологічним процесом, загальним для всіх живих організмів. Первинна емоція обмежена в часі й ініціюється зовнішнім стимулом. Кожній первинній як і вторинній емоції (комбінація декількох первинних емоцій) відповідає певний фізіологічний і експресивно-поведінковий комплекс. Для кращого розуміння важливих емоційних феноменів автор пропонує комбінувати первинні емоції, навіть взаємовиключні. Наприклад, емоція ненависті є результатом поєднання емоцій гніву та здивування тощо. Отже, аналіз ситуацій, які породжують у людини ненависть, і вияв очікувань людини щодо таких ситуацій дають змогу зрозуміти динаміку емоції ненависті зокрема [14].

У теорії диференціальних емоцій К. Ізард визначає емоцію як складний процес, що містить такі аспекти: нейрофізіологічний, нервово-м'язовий і чуттєво-переживаючий. Ней- 
рофізіологічний аспект емоцій визначається в термінах електрохімічної активності центральної нервової системи. На нервовом'язовому рівні емоція проявляється у вигляді мімічної активності, голосовими реакціями тощо. I на чуттєвому рівні емоція є переживанням, що має безпосередню значущість для людини. Нейрохімічні процеси викликають комплексні мімічні й соматичні прояви, які через зворотний зв'язок усвідомлюються, в результаті чого у людини виникає почуття/ переживання емоції, що мотивує людину й інформує про ситуацію. «Вплив емоцій на людину генералізовано, але кожна емоція діє на людину по-своєму. Переживання емоції змінює рівень електричної активності головного мозку, диктує, які м'язи обличчя й тіла повинні бути напруженими або розслабленими, керує ендокринною, кровеносною й дихальною системами організму» [3, с. 39].

П. Анохін вказував на емоції як стани організму з суб'єктивним забарвленням, які охоплюють почуття і переживання людини в діапазоні від страждань до радості [1]. Емоції розглядаються як біологічний продукт еволюціï, адаптивний фактор у житті людини. Виникнення потреб призводить до виникнення негативно забарвлених емоцій, які відіграють мобілізуючу роль, сприяючи найбільш швидкому задоволенню потреб оптимальним способом. Тобто, коли потреба задоволена, то виникає позитивна емоція. Закріплюючись у пам'яті, вона в майбутньому бере участь у мо- тиваційному процесі, впливаючи на ухвалення рішення про вибір способу задоволення потреби. Отже, повторне задоволення потреб, підкріплене позитивно забарвленою емоцією, сприяє закріпленню такої діяльності, а повторні невдачі викликають гальмування неефективної діяльності й пошуки нових, кращих способів досягнення мети.

Найконцентрованіше подання психоаналітиків про механізми виникнення емоцій знаходимо у Д. Рапапорта: «... сприйнятий ззовні перцептивний образ породжує несвідомий процес, в ході якого відбувається мобілізація неусвідомлюваної індивідом інстинктивної енергії; коли енергія не може знайти собі легального застосування (у випадку конфліктності інстинктивних потреб), тоді вона виходить назовні через інші канали у вигляді мимовільної активності; різні види такої активності - «емоційна експресія» та «емоційне переживання» - можуть виявлятися одночасно, почергово або незалежно один від одного; відкритий вияв інстинктивного потягу табуйовано культурою, й тому людині властиві постійні емоційні розрядки різної інтенсивності» [15, с. 37].

За теорією когнітивного дисонансу Л. Фестінгера, коли між очікуваними й дійсними результатами діяльності $\epsilon$ розбіжність (когнітивний дисонанс), виникають негативні емоції, у той час як збіг очікування й результату (когнітивний консонанс) приводить до появи позитивних емоцій. Виникаючі при ди- 
сонансі й консонансі емоції розглядаються в цій теорії як основні мотиви поведінки людини [10].

Отже, емоції виступають на передовій пізнання як зовнішнього, так і внутрішнього буття. Вони ніби сигналізують нам про світ, надаючи інформацію, якою ми оперуємо в когнітивній сфері, переробляємо й реагуємо на виклики цього світу. Афективна сфера від задоволення потреб індивіда через емоції й почуття до волі, здійснюючи своє функціональне призначення, бере участь у самотворенні особистості. У переживаннях індивідуалізується неповторний психічний світ особистості. В афективній сфері переживання виражається специфічно через ставлення особистості до неї, на відміну від когнітивної сфери, де відображення відбувається у формі образів. У когнітивній сфері ми маємо в образах зорову, слухову та інші модальності, а в емоційній сфері модальності - переживання радості, смутку тощо. Однак змістова сповненість цих форм відображення становить особливості когнітивної та афективної сфер психіки й, водночас, вказує напрямок, основу їх зближення, а саме, чуттєвість відображення, на основі якої виникають образи, та ії значущість. Відображення особистістю навколишнього світу відбувається з тієї специфічної життєвої позиції, яку вона в цьому світі займає.

Через емоції розпочинається взаємодія особистості з середовищем, яка спрямована на пізнання та знаходження себе в світі. На фено- менологічному рівні емоція виявляється як переживання, що має безпосередню значущість для суб'єкта. Адже зміни, які відбуваються в свідомості, змінюють емоційні переживання. Тобто, переживання як форма відображення в афективній сфері психіки особистості виступає як феноменологічний рівень емоцій.

Саме через переживання особистості виявляється ставлення до навколишнього світу, спонукання до дій, передбачення їхніх наслідків, пов'язаних з емоціями, з волею особистості. Вольове зусилля на феноменологічному рівні розглядається як переживання особливої внутрішньої роботи в ситуації необхідності здійснення дії за відсутності або слабкої вираженості спонукання до неї. Взаємозв'язок форм вияву переживань у когнітивній та афективній сферах можна представити так: проблемна ситуація $\rightarrow$ переживання $\rightarrow$ афективне відображення $\leftrightarrow$ когнітивне відображення $\leftrightarrow$ накопичення досвіду виходу з проблемної ситуації.

Вочевидь, переживання виступає в якості форми вияву ставлення особистості до об'єкта, самої себе, іншої особистості як до цінності та у формі даності нам нашого ставлення до того, що нас оточує, факт нашого внутрішнього накопиченого досвіду. Саме у переживаннях відбувається розгортання особистістю наявної події й її ставлення до неї, яке спонукають емоції. Тобто, відбувається постійне та циклічне «функціональне коло пережи- 
вань», на що вказував Ф. Лерш [4].

3 чого ж починається емоційне відреагування? На нашу думку, з процесу сприйняття. В. Барабанщиков зазначає: «... розгортання перцептивного процесу стає можливим завдяки взаємодії індивіда 3 навколишнім світом (середовищем), у ході якого змінюється й об'єкт сприйняття і він сам» [2, с. 24]. Автор, розглядаючи процес зорового сприйняття, акцентує увагу на таких моментах. Повинен бути суб'єкт сприйняття, кому воно належить. Крім того, оскільки об'єкт сприйняття залучений у подію, вона стає одиницею його життя, тим самим знаходить значення й зміст. Неузгодженість суб'єкта й об’єкта сприйняття є джерелом породження зорового образу й відповідного йому перетворення дійсності, тобто відносини індивіда з середовищем. Таким чином, чуттєва даність дійсності виявляється вписаною в реальний контекст життєдіяльності людини, в рамках якої розгортається іiі власна історія.

Ми поділяємо думку автора, оскільки перцептивні явища не існують самі по собі - $€$ суб'єкт сприйняття, який і відкривається назустріч дійсності. Він ініціює перцептивний процес, керує ним і розпоряджається продуктами сприйняття. У рамках аксіологічних відносин феномен сприйняття набуває вигляду переживання. Відповідно до отриманої інформації відбувається переструктурування згідно потреб, намірів, цінностей й очікувань особистості. Акцентуємо увагу на тому, що сприй- няття виражень містить емоційний компонент і змістовні утворення особистості, що є особливою межею внутрішнього світу.

Отже, емоційне відреагування залежить від змісту сприйнятого, порядку його перебігу в часі, способу організації, ступеня сповнення й деталізації. Нарешті, передумовою перцептивного процесу є психологічні особливості особистості: їі потреби, наміри, мотиви, відносини, оцінки, досвід, здатності, які в сукупності становлять внутрішні умови сприйняття.

Емоційні переживання забезпечують цей процес становлення, тобто власного перетворення особистості через значущі об'єкти, явища, інших суб'єктів. Так, ми поділяємо думку А. Адлера стосовно важливості перших подій у житті маленької дитини. Саме події дитинства проектуються й залишаються наближеними до основних життєвих інтересів. Особистість виступає суб'єктом і намагається реалізувати свої можливості, бути автором свого життя.

Отже, характеристики суб'єктивування суттєво впливають на емоційні переживання особистості, яка, на думку Г. Олпорта: «... швидше перехідний процес, ніж завершений продукт. Вона постійно змінюється. Саме цей процес зміни, становлення, індивідуації становить особливий інтерес» [6, с. 87]. Перефразовуючи автора, людина реалізує власний потенціал в постійному становленні, через суб'єктність особистість оцінює етапи свого життєвого шляху і відповідно до загальної задоволе- 
ності собою, від наявності бачення перспектив та багатьох інших факторів виставляє собі оцінки.

Окремі періоди життя можуть видаватися людині невиразно промайнулими саме тому, що переживання теперішніх подій не усвідомлюється в їхньому зв'язку з подіями минулого або невідомим залишається зміст цих подій для майбутнього, їх значення для оточуючих. Це дозволяє особистості через емоційні переживання реалізувати спрямовуючий вплив відповідності особистості світу у процесі взаємодії з ним. Під впливом індивідуальних особливостей суб'єкт переживає процес творення себе з метою досягнення ідеалу, спокою, внутрішньої свободи, тобто «тихої гавані»-гармонії зі світом.

Ми маємо змогу дещо ширше подивитися на проблему емоційності особистості, зокрема це стосуватиметься емоційності соціуму в якому проживає особистість. В житті українців емоції часто переважають над інтелектом і волею. В. Липинський наводить наступний приклад: «Нещасливе географічне положення, сприятливі дані природи і хаотична мішанина різних рас витворили в мешканцях України надмірну, часто пристрасну чутливість, якої не вдержують ослаблені легкою боротьбою за фізичне існування і причинами політичного характеру воля та інтелігентність» $[5$, с. 426$]$.

Інший автор Д. Чижевський також вказує на те, що безумовною рисою політичного укладу українця є його емоційність і сентименталізм, чутливість та ліризм, які найяскравіше виявляються в естетизмі українського народного життя і обрядовості, своєрідному українському гуморі [12]. Вчений підкреслює в українській емоційності її позитивні сторони, що відобразилися в українській духовній творчості, а В. Липинський навпаки показує негативні сторони емоційної сфери українців, що $є$ запорукою проблем як у політиці, так і в суспільному житті, і ми погоджуємося 3 автором, спостерігаючи події останніх місяців в Україні.

Є. Онацький зазначає: «Емоційність великий дар Божий, бо вона лежить в основі кожного мистецтва, кожної творчості, але в наших невмілих руках цей Божий дар перетворився в Божу кару. Від нас залежить повернути йй первісне, творче, а не руйнівне значення» $[7$, с. 6].

Видатний український філософ П. Юркевич обгрунтував українську емоційність через призму філософії у своїй роботі «Серце і його значення в духовному житті людини за вченням слова Божого» (1860). Вчений вказує на те, що саме серце $\epsilon$ основою фізичного й духовного життя людини, іiі емоційності, моральності.

Філософію серця сповідують у своїй творчості Г. Сковорода, М. Гоголь, П. Куліш, Т. Шевченко, про що детально й розлого вказує психологічна розвідка Я. Яреми «Українська духовість у іiі культурно- 
історичних виявах» (1937). «На думку Сковороди в цій глибинній, «серцевій» душі відбивається цілий космос, в ній $є$ й сам Бог, так що, пізнавши себе, своє серце, пізнаємо водночас цілий світ і Бога. Гоголь побачив у занедбанні цієї серцевої душі головну причину занепаду краси життя, а в іiі розцвіті - шлях до морального відродження» [13, с. 83]. Автор розглядає емоціоналізм українців через почуття як шлях пізнання людини і серце - основу душі, безодню, що породжує з себе поверхню свідомої душі. У центрі уваги українця знаходиться внутрішній світ моральної доброти, краси, перевага емоційності над інтелектом і волею.

Але емоційність може бути різною, наприклад, У. Джеймс згадує росіянку, яка за царських часів у театрі проливала сльози, але залишала власного візника мерзнути на морозі в той час, як слухала оперу. I далі вчений закликає викликані мистецтвом позитивні емоції не залишати для себе, а практично застосовувати, наприклад, піклуючись про ближніх [7].

Є. Онацький закликає до розвитку здорової емоційності в здоровій родині, сповідуючи Божу заповідь, любити ближнього свого. Родинне виховання сповідував і Б. Цимбалістий, який зауважив, що у переважної більшості українців їхнє дитинство, асоціюється з глибокою любов'ю до матері. Однак постать батька згадується невиразно, що свідчить про незначний вплив на їхнє життя в дитинстві. На- приклад, радянські українці, змогли зберегти релігійну свідомість, віру, завдяки віруючій матері, навіть під шаленим тиском атеїстичної пропаганди. В релігійному житті українців часто переважав культ Богоматері, ніж культ Богочоловіка, що спостерігається до цього часу.

Вчений, досліджуючи життя селян (виховання дітей) у Галичині, отримав такі результати: вихованням дітей займаються жінки, а батько зберігає за собою право час від часу на покарання дитини. Тобто батько для української дитини є недоступним та караючим авторитетом. Існує й інший тип батька доброго, лагідного, який опікується дитиною. Але загальна картина у вихованні дитини належить матері. Матріархальне виховання $є$ важливим наслідком у формуванні характеру української дитини. I це питання потребує додаткового вивчення, оскільки, згідно статистичних даних, у більшості українських сімей панує матріархат, хоч як не важко це визнавати сильній половині людства.

Які наслідки такого впливу на психіку дитини? Українська дитина не може легко ідентифікуватися з батьком, бо він мало нею цікавиться. Відповідно, вона ідентифікується 3 матір'ю, яка піклується й захищає від батька. Тобто норми, цінності, ідеали дитини підпорядковуються нормам, цінностям, ідеалам жіночої свідомості.

Звісно, що вплив батька існує, але сам батько дуже «материнський», якому притаманні доброта, добродушність, лагідність, ні- 
жність, м’якість, сердечність. Ці риси сприяють тому, що українська родина обирає життя в невеликих групах, де цінуються теплі взаємини, й майже відсутня позиція чоловіка здобувача, активність якого реалізується в зовнішньому світі. А це типово жіноча спрямованість на внутрішній світ. Наприклад, український, «батько-отаман», як ідеал, це не тип англійського військового провідника, відважного, енергійного, маломовного, ідейного, аскетичного, але це отаман, що всіма опікується, дбає за всіх, є зрозумілим для кожного, радиться перед кожним рішенням, тобто «отаман з материнськими рисами» [11].

Отже, емоційний вплив на розвиток українського народу та особистості зокрема відзначається у більшості наведених вище досліджень і тому ми маємо враховувати цей факт і в теперішніх реаліях. Маємо на увазі події на сході України. Учасники війни зазнають неспецифічного емоційного впливу, який в переважній більшості є негативним. Після деструктивних подій особистість погано спить, не може позбутися спогадів про травматичний досвід. Ці спогади з'являються проти волі людини й супроводжуються емоційним дистресом. Наслідки уникання можуть бути деструктивними, зокрема відмова від роботи, родини. Якщо людина прийшла до висновку, те, що сталося $є$ несправедливим або незаконним, «чому це зі мною?», «гірші живуть, а я потерпаю?» та ін., лише ускладнюватиме стосунки в сім'ї. Для відновлення фізичного і психічного здоров'я важливою $€$ підтримка сім’ї, родичів, друзів. Дружина, діти мають розуміти, що їхній батько змінився, він має проблеми і необхідно йому допомогти, відчуваючи його емоційний стан, а також тактовно супроводжувати його під час отримання професійної допомоги.

\section{Висновки і подальші перспективи} досліджень. Отже, емоції виступають на передовій пізнання як зовнішнього, так і внутрішнього буття. Вони ніби сигналізують нам про світ, надаючи інформацію, якою ми оперуємо в когнітивній сфері, переробляємо й реагуємо на виклики цього світу. Афективна сфера від задоволення потреб індивіда через емоції й почуття до волі, здійснюючи своє функціональне призначення, бере участь у самотворенні особистості. У переживаннях індивідуалізується неповторний психічний світ особистості. В афективній сфері переживання виражається специфічно через ставлення особистості до неї, на відміну від когнітивної сфери, де відображення відбувається у формі образів. У когнітивній сфері ми маємо в образах зорову, слухову та інші модальності, а в емоційній сфері модальності - переживання радості, смутку тощо. Однак змістова сповненість цих форм відображення становить особливості когнітивної та афективної сфер психіки i, водночас, вказує напрямок, основу їх зближення, а саме, чуттєвість відображення, на основі якої виникають образи та іiі значущість. Відображення особистістю навколишнього світу від- 
бувається з тієї специфічної життєвої позиції, яку вона в цьому світі займає.

Уточнено, особливості емоційності українців, де у центрі уваги знаходиться внутрішній світ, моральна доброта, краса, перевага емоційності над інтелектом і волею, сповідування «філософії серця». Матріархальне виховання характеру української дитини, що виявляється у ідентифікації з матір'ю їі цінностями, ідеалами, формує «жіночу свідомість» нацiï.

3'ясовано, що український емоціоналізм у сучасних умовах війни на сході України має бути врахований під час реабілітації учасників військових дій. Для відновлення фізичного і психічного здоров'я важлива підтримка родини.

\section{Перспективи подальшого вивчення} ми вбачаємо у з'ясуванні ролі емоційної сфери у вихованні дітей у сучасних українських сім'яX.

\section{Перелік використаних джерел:}

1. Анохин П. К. Значение ретикулярной формации для различных форм высшей нервной деятельности / П. К. Анохин // Физиологический журнал СССР. - 1957. - № 11. - C. 1072-1085.

2. Барабанщиков В. А. Восприятие и событие / Владимир Александрович Барабанщиков. - СПб. : Алетелея, 2002. - 512 c.

3. Изард К. Э. Психология эмоций / Кэррол Э. Изард; [пер. с англ. А. Татлыбаевой]. - СПб. : Питер, 2008. $464 \mathrm{c}$.
4. Лери Ф. Розуміння особи у психології // Гуманістична психологія: антологія в 3 т. / [за ред. : Р. Трача, Г. Балла]. - Т. 1. - К. : Пульсари, 2001. - С. 93 - 109.

5. Липинський В. «Листи до братів-хліборобів: про ідею і організацію українського монархізму» // В'ячеслав Липинський. - Відень, 1919-1926. - 580 с.

6. Олпорт Г. Личность в психологии / Гордон Олпорт. - М. : КСП+; СПб. : Ювента, 1998. - 325 с.

7. Онацький $C$. Українська емоційність / Проблеми: українська душа, Нью-Йорк - Торонто : В-во «Ключі», 1956. - C. 5-12.

8. Рождественський Ю. Т. Психологія в Україні XVII початку XIX ст. (спроба реконструкції та систематизації академічної спадщини) : монографія / Юрій Тихонович Рождественський. - Умань: ПП Жовтий, 2011. $252 \mathrm{c}$.

9. Симонов П. В. Мотивированный мозг. Высшая нервная деятельность и естественнонаучные основы общей психологии. / Павел Васильевич Симонов. - М.: Наука, 1987. - c. 267.

10. Фестингер Л. Теория когнитивного диссонанса / Леон Фестингер; [пер. с англ. А. Анистратенко, И. Знаешевой]. - М. : Речь, 2000. - 317 с.

11. Цимбалістий Б. Родина і душа народу / Б. Цимбалістий // Українська душа, Нью-Йорк - Торонто: В-во «Ключі», 1956. - С. 26-43.

12. Чижевський Д. Нариси з історії філософії на Україні. - Мюнхен, 1983. - 175 с.

13. Яким Ярема / Упорядкув., ред. і прим. С. Яреми. Львів: Видавничий центр ЛНУ імені Івана Франка, 2003. - 244 c.

14. Plutchik R. Psychophysiology of individual differences with special reference to emotions/R. Plutchik // Annual N. Y Acad. Sciense. - 1966. - V. 134. - № 2. - P. 776-781.

15. Rapaport D. On the psychoanalytic theory of motivation // M. R. Jones (ed.) Nebraska Symposium on Motivation. - Lincoln, NE. : University of Nebraska Press, 1960. - P. 173-257. 


\section{References (Transliteration):}

1. Anokhyn P. K. Znachenye retykuliarnoi formatsyy dlia razlychnikh form vusshei nervnoi deiatelnosty / P. K. Anokhyn // Fyzyolohycheskyi zhurnal SSSR. - 1957. - № 11. - S. 1072-1085.

2. Barabanshchykov V.A. Vospryiatye y sobutye / Vladymyr Aleksandrovych Barabanshchykov. - SPb. : Aleteleia, 2002. - $512 \mathrm{~s}$.

3. Yzard K. Psykholohyia эmotsyi / Kerrol Yzard; [per. s anhl. A. Tatlubaevoi]. - SPb. : Pyter, 2008. - 464 s.

4. Lersh F. Rozuminnia osoby u psykholohii // Humanistychna psykholohiia: antolohiia v 3 t. / [za red. : R. Tracha, H. Balla]. - T. 1. - K. : Pulsary, 2001. - S. 93 109.

5. Lypynskyi $V$. «Lysty do brativ-khliborobiv: pro ideiu i orhanizatsiiu ukrainskoho monarkhizmu»// Viacheslav Lypynskyi. - Viden, 1919-1926. - 580 s.

6. Olport H. Lychnost v psykholohyy / Hordon Olport. - M. : KSP+; SPb. : Yuventa, 1998. - 325 s.

7. Onatskyi Ye. Ukrainska emotsiinist / Problemy: ukrainska dusha, Niu-York - Toronto : V-vo «Kliuchi», 1956. - S. 5-12.

8. Rozhdestvenskyi Yu. T. Psykholohiia v Ukraini XVII - pochatku XIX st. (sproba rekonstruktsii ta systematyzatsii akademichnoi spadshchyny) : monohrafiia / Yurii Tykhonovych Rozhdestvenskyi. - Uman: PP Zhovtyi, 2011. - $252 \mathrm{~s}$.

9. Symonov P. V. Motyvyrovannыi mozgh. Vыsshaia nervnaia deiatelnost y estestvennonauchnыe оsnovы obshchei psykholohyy. / Pavel Vasylevych Symonov. - M.: Nauka, 1987. - s. 267.

10. Festynher L. Teoryia kohnytyvnoho dyssonansa / Leon Festynher; [per. s anhl. A. Anystratenko, Y. Znaeshevoi]. - M. : Rech, 2000. - 317 s.

11. Tsymbalistyi B. Rodyna i dusha narodu / B. Tsymbalistyi // Ukrainska dusha, Niu-York - Toronto: Vvo «Kliuchi», 1956. - S. 26-43.

12. Chyzhevskyi D. Narysy z istorii filosofii na Ukraini. - Miunkhen, 1983. - 175 s.
13. Iakym Yarema / Uporiadkuv., red. i prym. S. Yaremy. - Lviv: Vydavnychyi tsentr LNU imeni Ivana Franka, 2003. - 244 s.

14. Plutchik R. Psychophysiology of individual differences with special reference to emotions/R. Plutchik // Annual N. Y Acad. Sciense. - 1966. - V. 134. № 2. - P. 776-781.

15. Rapaport D. On the psychoanalytic theory of motivation // M. R. Jones (ed.) Nebraska Symposium on Motivation. - Lincoln, NE. : University of Nebraska Press, 1960. - P. 173-257.

\section{Andriy Maslyuk}

Ph.D., Senior researcher G.S. Kostiuk Institute of Psychology of the National Academy of Educational Sciences of Ukraine, Kyiv (Ukraine)

\section{THE INFLUENCE OF EMOTIONAL STATES ON THE DEVELOPMENT OF THE PERSON}

\section{ABSTRACT}

Emotions are on the advanced knowledge of both external and internal being. They seem to signal us about the world, providing information, which we operate in the cognitive sphere, we process and respond to the challenges of this world. The affective sphere from satisfying the needs of the individual through emotions and feelings for freedom, fulfilling its functional purpose, participates in the self-creation of the individual. In experiences, the individual psychic world of the individual is individualized. In the affective sphere of experience is expressed specifically through the relation of the individual to it, in contrast to the cognitive sphere, where the mapping takes place in the form of images. In the cogni- 
tive sphere we have in the images visual, auditory and other modalities, and in the emotional sphere of modality - the experience of joy, sadness and the like. However, the substantial fulfillment of these forms of reflection constitutes the peculiarities of the cognitive and affective spheres of the psyche and simultaneously indicates the direction, at the basis of their convergence, namely, the sensuality of the image on the basis of which images and its significance arise. The person's depiction of the world around him is based on the specific life position that she takes in this world.

Clarified, the peculiarities of the emotionality of Ukrainians, where the inner world, moral kindness, beauty, the advantage of emotionality over intellect and will, the confession of the «philosophy of the heart» are in the center of attention. Matriarchal education of the character of the Ukrainian child, manifested in the identification with the mother of her values, ideals, forms the "female consciousness" of the nation.

It was found out that the Ukrainian emotionalism in the modern conditions of war in the east of Ukraine should be taken into account when rehabilitating the participants in military operations. For the restoration of physical and mental health, family support is important.

Prospects for further study we see in clarifying the role of the emotional sphere in the upbringing of children in modern Ukrainian families.

Key words: upbringing, emotion, morality, personality, experiences, family, development.

\section{Маслюк Андрей Николаевич}

Кандидат психологических наук, стариий научный сотрудник лаборатории общей психологии и истории психологии им. В. А. Ромения, Института психологии имени Г. С. Костюка НАПН Украинь,, Киев (Украина)

\section{ВЛИЯНИЕ ЭМОЦИОНАЛЬНЫХ СОСТОЯНИЙ НА РАЗВИТИЕ ЛИЧНОСТИ}

Аннотация. Эмоции выступают на передовой познания как внешнего, так и внутреннего бытия. Они как бы сигнализируют нам о мире, предоставляя информацию, которой мы оперируем в когнитивной сфере, перерабатываем и реагируем на вызовы этого мира. Аффективная сфера от удовлетворения потребностей индивида через эмоции и чувства к свободе, осуществляя свое функциональное назначение, участвует в самосозидании личности. В переживаниях индивидуализируется неповторимый психический мир личности. В аффективной сфере переживания выражается специфически через отношение личности к ней, в отличие от когнитивной сферы, где отображение происходит в форме образов. В когнитивной сфере мы имеем в образах зрительную, слуховую и другие модальности, а в эмоциональной сфере модальности - переживание радости, грусти и тому подобное. Однако содержательная исполненность этих форм отражения составляет особенности когнитивной и аффективной сфер психики и одновременно указывает направление, в основе их 
сближения, а именно, чувственность отображения, на основе которой возникают образы и ее значимость. Отображение личностью окружающего мира происходит по той специфической жизненной позиции, которую она в этом мире занимает.

Уточнено, особенности эмоциональности украинцев, где в центре внимания находится внутренний мир, моральная доброта, красота, преимущество эмоциональности над интеллектом и волей, исповедание «философии сердца». Матриархальное воспитания характера украинского ребенка, проявляющееся в идентификации с матерью ее ценностями, идеалами, формирует «женское сознание» нации.

Выяснено, что украинский эмоционализм в современных условиях войны на востоке Украины должен быть учтен при реабилитации участников военных действий. Для восстановления физического и психического здоровья важна поддержка семьи.

Перспективы дальнейшего изучения мы видим в выяснении роли эмоциональной сферы в воспитании детей в современных украинских семьях.

Ключевые слова: воспитание, эмоция, нравственность, личность, переживания, семья, развитие. 